\title{
Response of wheat varieties to salinity: growth, yield and ion analysis
}

\author{
Hina Nazeer ${ }^{1}$, Humaira Gul ${ }^{1}$, Mamoona Rauf ${ }^{1}$, Tabassum Yaseen ${ }^{2 *}$, Khushnood Ur Rehman ${ }^{3}$, Yaseen \\ $\mathrm{Khan}^{4}$, Bakht Amin ${ }^{5}$, Sulaiman Shah ${ }^{6}$, Mohib Shah ${ }^{1} \&$ Muhammad Noor \\ ${ }^{1}$ Department of Botany, Abdul Wali Khan University, Mardan, Khyber Pukhtunkhuwa, Pakistan \\ ${ }^{2}$ Department of Botany, Bacha Khan University, Charsadda, Khyber Pukhtunkhuwa, Pakistan \\ ${ }^{3}$ Department of Botany, Islamia College University, Peshawar, Pakistan \\ ${ }^{4}$ Key Laboratory of Plant Nutrition and Agri-environment in Northwest China, Ministry of Agriculture, College of Natural Resources and \\ Environment, Northwest A\&F University, Yangling, Shanxi-China \\ ${ }^{5}$ College of Horticulture, Northwest A\&F University, Yangling 71210, China \\ ${ }^{6}$ Department of Botany, University of Malakand Chakdara, Khyber Pukhtunkhuwa, Pakistan \\ ${ }^{7}$ Department of Agriculture, Hazara University, Pukhtunkhuwa, Pakistan \\ *Email: tabassumyaseen@bkuc.edu.pk
}

\section{ARTICLE HISTORY}

Received: 25 December 2020

Accepted: 11 February 2021

Published: 01 April 2021

\section{KEYWORDS}

Triticum aestivum

Vegetative growth

Chloride

Reproductive growth

RWC

Electrolyte leakage

Sodium

\section{ABSTRACT}

In plants, development, growth and yield most severely affected through saline soil/water in growth medium, ultimately cause severe threat to global food production for human being. Wheat (Triticum aestivum) is the most edible crop in Pakistan. Production of this crop can be improved through using marginal areas with the help of growing salt-tolerant varieties. The present investigation is carried out to screen out six local wheat varieties (F.Sarhad, Insaf, Lalma, Tatora, Bathoor and Barsat) with reference to their vegetative and reproductive growth, different physiological parameters [relative water content (RWC), electrolyte-leakage (EL) and leaf water loss (LWL)] and ionic status of plants. Present experiment designed in completely randomized manner (CRD) and 54 pots were arranged in the Botanical Garden, Department of Botany. These pots arranged in 6 lines with 9 pots/line and each line was irrigated with non-saline (control), $50 \mathrm{mM}$ and $150 \mathrm{mM} \mathrm{NaCl}$ solution. The data from present research revealed that application of salt cause significant reduction in plant-height, root-length, freshbiomass, dry-biomass, seed number/plant, seed weight/plant, spike-weight, relative water content, leaf water loss, and different ions of plants. Similarly at same applied doses of salt weight of 100 seeds, spike-length, electrolyte-leakage, $\mathrm{Na}+$ and $\mathrm{Cl}$ - ions become increased. It has been concluded from the results of present study that varieties F. Sarhad, Insaf and Lalma exhibited more salt tolerance as compare to other varieties. So, these recommended for growing on moderately salt affected soil/water to achieve more yield of wheat from such affected lands of Khyber Pakhtunkhwa, Pakistan.

\section{Introduction}

Wheat (Triticum aestivum L.) regarded as a vital cereal crop worldwide and contributes as staple food for one-third of world population. This plant functioned as important part of development of civilization and is a major source of food with dense and preferred grown and consumed in Pakistan. This plant contains $1.5-2 \%$ fat, $2-2.5 \%$ glucose, $60-80 \%$ proteins and $2-3 \%$ mineral content in it (1). Different parts of this plant used medicinally as wheat-grass juice is considered as antioxidant and used to treat ulcerative-colitis, which is helpful for patients of breast cancer who received chemotherapy, as well as used for the treatment of other different health problems (2). Different components of wheat-grass used for ulcerative-colitis (3), cancer treatment (4) and joint-pain, and it is also used as anti-oxidant (5). So, all wheat varieties (including bran and wheat-germ), provide protection against different diseases e.g. constipation, diabetes, obesity, heart-diseases, appendicitis and diverticulum (6).

Among different abiotic stress factors, saline soil/saline water is a major factor that involved in reduction of crops growth and development and yield in world's different arid and semi-arid regions (7). About 800 million hectares of world total land and 32

(c) Nazeer et al. (2021). This is an open-access article distributed under the terms of the Creative Commons Attribution License, which permits unrestricted use, distribution and reproduction in any medium, provided the original author and source are credited (https://creativecommons.org/licenses/by/4.0/).

To cite this article: Nazeer H, Gul H, Rauf M, Yaseen T, Rehman K U, Khan Y, Amin B, Shah S, Shah M, Noor M. Response of wheat varieties to salinity: growth, yield and ion analysis. Plant Science Today. 2021;8(2):301-311. https://doi.org/10.14719/pst.2021.8.2.1074 
million-hectares of world agricultural land is severely affected by salinity problem (106). pH of saline soil usually ranges between 7-8.5 (8). Presence of high amount of salt in soil/water cause negative effects on crop growth and production (9) through disturbing different processes e.g. germination of seeds, different phases of seedling growth and development. These disturbances caused as a result of toxicity of specific ions with high osmotic potential (9). When plants expose to salinity stress it alter its physiology at cellular level (10), first through creation of osmotic stress then second toxic ions effect induced (11). This stress also had adverse effects on uptake of different nutrients as a result of osmotic and ionic imbalance. This disturbed process cause reduction in plant height, production of tillers and leaves and finally result in low yield production (12). At cellular level presence of imbalance ions cause due to the presence of high amount of sodium and chloride ions which cause reduction in uptake of other important nutrients e.g. calcium, potassium, magnesium etc. (107).

As problem of salinity is quite important world wide, so different strategies used to over-come harmful effects of this problem on plant growth and metabolism, e.g. salt-tolerant cultivars production using breeding programme, foliar application of different metabolites etc. plant breeding programme is very useful for production of salt tolerant and more yield producing lines, while its use is limited as a result of multi genic nature of salt tolerance as well as large genetic variation in crops (13). For improvement of salt tolerance this breeding programme needs effective screening techniques for selection and then evaluation of specified traits. Another requirement is the identification of geneticvariability with knowledge of tolerance-traits inheritance and mechanism of tolerance mechanism in biological system on different stages of development of plants. It is also necessary to use reliable and suitable design and indirect and direct selection criteria, most appropriate breeding strategy/methodology for the transfer of tolerance characters to better genetic-background (14). Present research was designed to evaluate salt tolerance of some local wheat varieties in terms of measuring their vegetative parameters, reproductive parameters, some physiological attributes, cations and anions status of plants.

\section{Materials and Methods}

To set an experiment, Wheat (Triticum aestivum) different varieties (F. Sarhad, Insaf, Lalma, Tatora, Bathoor and Barsat) seeds were collected from Agriculture Research Institute Tarnab Peshawar, Khyber Pakhtunkhwa. Obtained seeds were sown in 54 pots ( 5 seeds/pot), while 54 pots were divided into 6 sets and each set contain 9 pots. Experiment was designed in completely-randomized-design and three treatments i.e., 0 (non-saline) and $\mathrm{NaCl}$ application @ $50 \mathrm{mM}$ and $150 \mathrm{mM}$ were maintained with three replicates/ treatment. $0.1 \%$ mercuric-chloride solution was applied on seeds for surface-sterilization then sown in pots. Pots were filled with sandy loam soil while each pot had basal outlet for drainage purpose. All pots (each having five seeds) were arranged in completely randomized design. This experiment was carried out under natural environmental condition in Botanical Garden, Department of Botany, Abdul Wali Khan University Mardan. Irrigation of pots was performed with equal amount of tap water, from the beginning till three leaf stage. After two weeks of germination (three leaves stage) seedlings were irrigated, twice a week, with different salt concentrations. After completion of six months, experiment was terminated and plants were harvested. Different agronomic characters (Plant height, root-length, fresh biomass and drybiomass, spike length, spike biomass, seed number/plant, seed weight/plant) were recorded.

\section{Measuring Leaf Relative water content (RWC)}

RWC of fresh leaf sample was calculated through defined method (15). Leaf sample (fresh) was first weighed and then kept for rehydration process in deionized water for 2 hrs. Rehydration process completed in assigned time period then turgor weight was measured. Dry weight of leaf samples were measured after incubating samples in preheated oven. RWC was calculated using following formula.

$$
\text { RWC }(\%)=(\text { F-Wt. }- \text { D-Wt. }) /(\text { T-Wt. }- \text { D-Wt. }) * 100
$$

\section{Measuring Leaf Electrolyte leakage (EL)}

EL (Electrolyte leakage) of fresh leaves was determined through standard procedure (16). $0.3 \mathrm{gms}$ fresh leaf sample was incubate in tube contain $15 \mathrm{ml}$ D. $\mathrm{H}_{2} \mathrm{O}$ for $2 \mathrm{hrs}$, at $25{ }^{\circ} \mathrm{C}$ in incubator. After $2 \mathrm{hrs}$ EC of solution (L1) was recorded. Sample was autoclaved for 20 minutes then solution's electrical-conductivity (L1) was determined. Autoclave all samples at $120^{\circ} \mathrm{C}$ for 20 mins, then measuring of final EC (L2) was performed in further step, at equilibrium and at 25 ${ }^{\circ} \mathrm{C}$. Calculation of electrolyte leakage was performed through given below formula:

$$
\mathrm{EL}(\%)=\mathrm{L} 1 / \mathrm{L} 2 * 100
$$

\section{Measuring Leaf water loss (LWL)}

Leaf Water Loss was determined through a process explained (17). Fresh-leaf samples were collected then initial weight (W1) was recorded. Sample was kept for $2 \mathrm{hrs}$ at $30{ }^{\circ} \mathrm{C}$ and then sample was weighed again (W2). LWL was calculated using following formula.

$$
\text { LWL }(\%)=\mathrm{W} 1-\mathrm{W} 2 / \mathrm{W} 1 * 100
$$

\section{Soil analysis}

For EC and pH analysis, soil samples were collected after termination of experiment. Soil samples were dried then saturation was performed with de-ionized water. Saturated material was placed for $24 \mathrm{hrs}$ and then water extracted out from material under vacuum (USDA, 1954). Electrical-conductivity and $\mathrm{pH}$ of solution was measured with Conductivity meter and $\mathrm{pH}$ meter (62).

\section{Analysis of different Minerals}

Plant samples were collected for the analysis of different cations $(\mathrm{K}+, \mathrm{Na}+\mathrm{Mg}+2$ and $\mathrm{Ca}+2) .0 .5 \mathrm{gm}$ of dried plant material was used for the determination 
of ash weight. Ash was mixed in $50 \mathrm{ml}$ deionized water and solution was used for making dilutions with help of deionized water for analysis of different cations. Cations concentration in different samples was recorded using Atomic-AbsorptionSpectrophotometer (8).

\section{Statistical Analysis}

Data of different factors was analyzed for analysis of variance (Two-way ANOVA) using SPSS (Ver. 21). Means of different treatments were analyzed and compared using DMRT (Duncan's multiple range test) at $\mathrm{P}<0.05$ level.

\section{Results and Discussion}

\section{Vegetative traits}

Plant growth consists of potential of germination process, hypocotyle length, fresh and dry Biomass, seedling growth and vegetative growth of plants, mainly caused through cell division, cell differentiation and cell enlargement, while different factors in environment cause changes in these parameters. Obtained results from current study revealed that high salt level $(150 \mathrm{mM} \mathrm{NaCl})$ application on wheat varieties caused significant reduction in plant height as compare to their control. Reduction percentages at high salinity level were recorded as $18.8 \%, 24.3 \%, 33.5 \%, 23.7 \%, 24.1 \%$ and $17.4 \%$ in F. Sarhad, Insaf, Lalma, Tatora, Bathoor and Barsat respectively. Barsat and F. Sarhad varieties showed best performance for studied parameter as compare to other varieties. In different studies (1821) this fact showed that high salt level induction causes negative impact on its quality nd quantity of yield. Observations of (22) on Triticum aestivum genotypes revealed reduction in plant height as a result of high level of salt accumulation in root zone, which results in reduction of essential nutrients and water. In another study (23) on Oryza sativa while (24) in cowpea (Vigna unguiculata L.) obtained same results.

In general for plant growth and development, in broad terms for plant biomass and yield, height of plant and root growth (formation and elongation) both are indictors for formative and morphological phenotypes of any plant. Currently, high salt level (150 mM NaCl) application on wheat varieties caused significant reduction in root length as compare to their control. Reduction percentages at high salinity level were recorded as $29.5 \%, 20.3 \%, 34.3 \%, 15.8 \%$, $34.1 \%$ and $42.5 \%$ in F. Sarhad, Insaf, Lalma, Tatora, Bathoor and Barsat respectively. Tatora and F. Sarhad varieties showed best performance for studied parameter as compare to other varieties. Studies are on Catharanthus roseus under salinity stress and observed reduced root growth of plants as compare to control (25). In an another study on rice plant and observed reduction in root length as a result of inhibition effect of applied sodium chloride in growth medium (26). Salt in growth medium cause toxic effect on root penetration with meristematic cells growth (elongation and division) which automatically reduce the root length of plant (27).
In crops and other plants, process of growth and development did not proceed at fixed/constant rate. Developmental progress in plants, leads to plant growth, recognized by increase in size of different organs with accumulation of dry biomass. This increase first caused through sugars and then, formation of storage and structural material in fruits leaves and stems (28). During the present investigation high salt level $(150 \mathrm{mM} \mathrm{NaCl})$ application on wheat varieties caused significant reduction in fresh biomass as compare to their control (Fig. 1C). Reduction percentages at high salinity level were recorded as $66.3 \%, 72.3 \%$, $78.9 \%$, $52.6 \%, 55.1 \%$ and $60.2 \%$ in F. Sarhad, Insaf, Lalma, Tatora, Bathoor and Barsat respectively. Tatora and Barsat varieties exhibited best performance for studied parameter as compare to other varieties. According to one study salt stress application cause reduction in seedling's fresh and dry biomass as a result of reduced uptake of water under such harsh condition (29). Study on Pisum sativum revealed reduction in fresh weight of seedlings under salinity stress condition (30). Saline environment causes reducing effect in plants, due to inhibitory effects on opening and closing of stomata, process of photosynthesis, inter cellular concentration of carbon dioxide which ultimately causes reducing effects on enzymes, carotenoids and chlorophyll molecules (31). Limited plant growth, occurs through decrease in process of photosynthesis with uptake of high level of salts. These salts also disturb specific metabolites production, which are important for proper plant growth (32).

Different experiments concluded that partitioning of biomass between shoots and roots is strictly affected by the resources, which are of limited growth under stressed-condition and deficiency of this resource mostly ameliorate by increased biomass allocation to those parts of the plant which are responsible for acquiring very important limitingresource (33). During the present investigation, high salt level (150 mM NaCl) application on wheat varieties caused significant reduction in dry biomass as compare to their control (Fig. 1A). Reduction percentages at high salinity level were recorded as $45.7 \%, 63.3 \%$, 55.09\%, 12.6\%, 45.6\% and $8.04 \%$ in F. Sarhad, Insaf, Lalma, Tatora, Bathoor and Barsat respectively. Tatora and Barsat varieties exhibited best performance for studied parameter as compare to other varieties. Observations are on the reduction in dry matter of seedling when raised under saline stress condition (34). Under saline conditions, sodium and chloride ions accumulate at toxic level with osmotic imbalance in plants resulted in reduced dry weight of plant $(35,36)$. Plant exposure to salinity stress cause reduction in dry biomass might be as a result of huge reduction in photosynthetic-rate of particular plant (37). In an another study, it stated that reduction in dry weight of seedlings after exposure to saline environment could be attributed to low nutrients uptake from saline soil (38).

\section{Reproductive parameters}

In plants, for the process of growth and development, different environmental stresses cause negative impact on plant growth and metabolism and are 
responsible for reduction in the amount of harvestable produce. During the present research, high salt level (150 mM NaCl) application on wheat varieties caused significant reduction in seed number per plant (Fig. 2B) except Insaf which showed promotion as compare to their control. Reduction percentages at high salinity level were recorded as $51.6 \%, 56.6 \%, 20 \%, 33.3 \%$ and $83.3 \%$ in F. Sarhad, Lalma, Tatora, Bathoor and Barsat respectively while variety Insaf exhibited $56.5 \%$ promotion. Insaf and Tatora varieties exhibited best performance for studied parameter as compare to other varieties (39) explained different harmful impacts of salinity stress on plant metabolism, he stated that salt stress cause imbalances in ionomics and osmotic processes of plant which ultimately caused disturbed physiological and biochemical processes with reduction in growth and final yield. Currently, high salt level (150 mM NaCl) application on wheat varieties caused significant reduction in seed weight per plant (Fig. 2C) except Insaf which showed promotion as compare to their control. Reduction percentages at high salinity level were recorded as $48.7 \%, 66.8 \%, 15 \%, 42.5 \%, 81.2 \%$ in F.Sarhad, Lalma, Tatora, Bathoor and Barsat respectively while variety Insaf exhibited $51.3 \%$ promotion. Insaf and Tatora varieties exhibited best performance for studied parameter as compare to other varieties (Fig. 1AC).

Reduction in grains number and mean grain size after exposure of plant to salt stress cause considerable decrease in grain yield per plant (40). In another study, (41) observed lentil grown in saline environment and obtain reduced seed weight as a result of reduced carbon metabolism. In the present study, high salt level (150 $\mathrm{mM} \mathrm{NaCl})$ application on wheat varieties caused significant reduction in seed number per plant (Fig. 2B) except Tatora which showed promotion as compared to their control. Reduction percentages at high salinity level were recorded as $0.8 \%, 13.7 \%, 21.7 \%, 13.9 \%$ and $43.7 \%$ in F. Sarhad, Insaf, Lalma, Bathoor and Barsat respectively while variety Tatora exhibited 9.1\% promotion. Tatora and F. Sarhad varieties exhibited best performance for studied parameter as compare to other varieties. Works on barley plants grown in saline condition and observed reduction in seed number, seed weight and weight of 1000 seeds under such condition (42) (Fig. 2BC). He explained that grain/seed number and weight are quite sensitive parameters to stress condition in fields and account for most of the decrease in yield of any studied plant. Reduction in total yield of Triticum aestivum cultivars under saline environment could be attributed to reduced dry-weight of shoot and spike of salt-exposed plants (43) (Fig. 2AD).

Plants are influenced by many exogenous and endogenous factors that had good or bad impact on their growth. Use of insecticides is exogenous factor and has been used extensively to control disease pathogen and insects on plants while at the same time these insecticides had effects either beneficial or hazardous on plant growth. Obtained results revealed that high salt level $(150 \mathrm{mM} \mathrm{NaCl})$ application on wheat varieties caused significant reduction in spike weight except Lalma and Bathoor which showed reduction as compared to their control. Promotion percentages at high salinity level were recorded as 9.5\%, 13.6\%, 72.4\%, 46.4\% and $24 \%$ in F. Sarhad, Insaf, Lalma, Bathoor and Barsat respectively while variety Tatora exhibited $4.2 \%$ promotion. Tatora and F. Sarhad varieties exhibited best performance for studied parameter as compare to other varieties. Reports states that $\mathrm{NaCl}$ which is toxic in high amount and caused reduction effect in the development of shoot and root as well as cause imbalance in uptake of different nutrients due to competition of sodium and chloride with other cations and anions (44). This fact may result in reduction of growth, development and yield of plant. Currently, high salt level (150 mM NaCl) application on wheat varieties caused significant promotion in seed number per plant except Lalma and Bathoor which showed promotion as compare to their control. Promotion percentages at high salinity level were recorded as $2.8 \%, 12 \%, 25.9 \%$, and $8.4 \%$ in $\mathrm{F}$. Sarhad, Insaf, Tatora and Barsat respectively while variety Lalma and Bathoor exhibited $19.5 \%$ and $16.9 \%$ reduction. Tatora and F. Sarhad varieties exhibited best performance for studied parameter as compared to other varieties. In most crops when plant expose to salt stress at any developmental stage of plant led to minimize reproductive and vegetative growth components (45). Another cause of reduction in the number of seed is due to reduced pollenviability and non receptiveness of stigmatic area (46). Salinity induced number of seed/plant reduces because of many biochemical and physiological disturbances in non halophytic plants which grown in saline condition (47).

\section{Relative Water Content}

The relative water content technique is used to describe plant water status and formerly known as relative turgidity. Obtained results revealed that high salt level $(150 \mathrm{mM} \mathrm{NaCl})$ application on wheat varieties caused significant reduction in relative water content as compare to their control. Reduction percentages at high salinity level were recorded as $19.4 \%, 18.5 \%, 20.7 \%, 11.4 \%, 28.1 \%$ and $47.7 \%$ in $\mathrm{F}$. Sarhad, Insaf, Lalma, Tatora, Bathoor and Barsat respectively (Fig. 3A). Tatora, Insaf and F. Sarhad varieties exhibited best performance for studied parameter as compare to other varieties. While working on jute seedling under salinity stress, it was observed that the reduction in growth occur as a result of low water content in plant cells (48). The Work of $(49,50)$ on soybean genotypes revealed reduction in relative water content under salt stress condition. Reduction in relative water content of cell increased after exposure of plants to salt stress, mainly caused as a result of reduced membrane integrity (51). Increase in salinity levels cause decrease in RWC due to reduced water supply to cells, sodium ions accumulation in cytoplasm of cell and competition of sodium with potassium ions (52). Enhanced sodium ions in cells cause reduction in osmotic potential.

\section{Electrolyte Leakage}

Different environmental factors cause different types of physiological response and oxidative damage in different plants species. These environmental factors 
are able to cause intra cellular over production of ROS (reactive oxygen species) resulting in damage to cells. Reaction between radicals of ROS and different macromolecules e.g. lipoprotein, this process cause more rapid peroxidative damage which is evident from destruction of lipid membrane (108). Increased rate of electrolyte leakage has been used as an indicator of physical damage to cell membranes. During the present investigation, high salt level (150 $\mathrm{mM} \mathrm{NaCl)}$ application on wheat varieties caused significant promotion in plant height as compare to their control. Promotion percentages at high salinity level were recorded as $138.09 \%, 51.08 \%$, 155.1\%, $125 \%, 30.7 \%$ and $50.8 \%$ in F. Sarhad, Insaf, Lalma, Tatora, Bathoor and Barsat respectively (Fig. 3C). Bathoor and Barsat varieties exhibited best performance for studied parameter as compare to other varieties. After exposure to salt stress plant's electrolyte leakage enhanced as a result of oxidative damage to different lipds and collectively cell membrane $(53,54)$. Experiments revealed enhanced value of electrolyte leakage in plants as during stress sodium ions accumulation in cell cause lesion in the cell membrane and this damage cause more electrolytes leakage as compare to control plants (55, 56). Electrolyte leakage showed marked increase in plants under any stress conditions. Under such conditions different electrolytes e.g. potassium ions excreted out from the cell after cell death under stress condition which results in loss of membrane integrity. So, this loss of electrolytes from cells of any plant under stress condition, used as a criterion for measurement of dead cell in the tissue (57).

\section{Leaf Water Loss}

Water status determination methods in plants are leaf water loss (LWL) and relative water content (RWC) that are very quick and easy methods. During present research, high salt level $(150 \mathrm{mM} \mathrm{NaCl})$ application on wheat varieties caused significant reduction in plant height as compared to their control. Reduction percentages at high salinity level were recorded as 56.4\%, 36.8\%, 65.4\%, 45.4\%, 46.9\% and $39.3 \%$ in F. Sarhad, Insaf, Lalma, Tatora, Bathoor and Barsat respectively (Fig. 3B). Insaf and Barsat varieties exhibited best performance for studied parameter as compared to other varieties (58) explained about the reduction of water content in any plant under salt stress due to reduction in water uptake through plants and accumulation of toxic ions in cytoplasm of cell. LWL determination in plants under such condition revealed the residual transpiration connected with water loss through stomata which were least open. Reduced transpirational rate in plants after exposure to saline stress environment worked out in different Brassica species (59) and in amaranth (60). High salt concentration in growing medium causes reduction in water potential of leaves, in different salt tolerant varieties. Inhibition in water potential achieved through low osmotic potential and leaf turgidity maintained during salt stress condition in plants (6162).

\section{Ions Analysis}

Sodium ( $\left.\mathrm{Na}^{+}\right)$
For normal growth, development and proper physiological functions in plants, appropriate ions ratio is very important (63). Results of this research revealed that high salt level $(150 \mathrm{mM} \mathrm{NaCl})$ application on wheat varieties caused significant promotion in sodium ions in both shoot and root regions as compare to their control. Reduction percentages at high salinity level were recorded in shoot as $986.8 \%, 1113.1 \%, 291.1 \%, 710.7 \%, 801.8 \%$ and $419.3 \%$ while in root region values were observed as $42.2 \%, 106.7 \%, 38.8 \%, 197.7 \%, 121.5 \%$ and $74.3 \%$ in F. Sarhad, Insaf, Lalma, Tatora, Bathoor and Barsat respectively. Lalma and F. Sarhad varieties exhibited best performance for studied parameter as compare to other varieties (Fig. 3D). Application of high salt concentration to plants modifies different biochemical and physiological processes of plant through osmotic and ionic stress (64). High concentration of sodium and chloride results in creation of osmotic stress in the medium, so due to this action reduced water content available to plant tissues. Another phenomenon as a result of high concentrations of toxic ions in medium is the production of ionic stress, results in the metabolic disturbances in plant due to accumulation of toxic ions (e.g. sodium and chloride), that reduced to uptake of essential minerals (e.g. calcium and potassium) in plants (65).

\section{Potassium (K+)}

Potassium is essential element for plant growth and development, responsible for maintaining cell turgor and osmotic adjustment. This element is also known as major cation in plants maintain balance the negative charge of different anions. It also has important function for enzymes activation, responsible for carbohydrate and protein synthesis, with regulation of stomatal movement in plants (66). During present study, high salt level (150 mM NaCl) application on wheat varieties caused significant reduction in plant height in both shoot and root regions as compare to their control. Reduction percentages at high salinity level were recorded in shoot as $44.3 \%, 28.5 \%, 47.6 \%, 29.1 \%, 27.8 \%$ and $27.1 \%$ while in root region values were observed as $21.9 \%$, $61.5 \%, 73.2 \%, 35.5 \%, 65.7 \%$ and $42.9 \%$ in F. Sarhad, Insaf, Lalma, Tatora, Bathoor and Barsat respectively. Barsat and F. Sarhad varieties exhibited best performance for studied parameter as compare to other varieties. With increase in salt concentration in soil, concentration of different ions also increased in soil, which starts competition in the root medium under uptake process, with those minerals that are essential for growth of plant (63). Under salt stress, sodium compete with potassium for binding site with deficiency of potassium and toxicity of sodium ions, which results in deactivation of important functions of enzymes and cells (1).

\section{Calcium (Ca+)}

Calcium is important divalent cation play important role in plant metabolism and growth. Intra cellular calcium is responsible to regulate response of salt stress as well as drought stress. this element perform function for signal transduction for salinity and drought stress in plants, as well as had important role 
in osmoregulation under different environmental stresses $(67,68)$. Results of the present study revealed that high salt level $(150 \mathrm{mM} \mathrm{NaCl})$ application on wheat varieties caused significant reduction in plant height in both shoot and root regions as compare to their control. Reduction percentages at high salinity level were recorded in shoot as $41.9 \%, 17.9 \%, 13.3 \%$, $18 \%, 26 \%$ and $63.7 \%$ while in root region values were observed as $24 \%$, 32.7\%, 4.2\%, 8.6\%, 66.5\% and 36.5\% in F.Sarhad, Insaf, Lalma, Tatora, Bathoor and Barsat respectively. Lalma and F.Sarhad varieties exhibited best performance for studied parameter as compare to other varieties. Under stress condition, uptake of salts create specific ion toxicity (e.g. sodium, chloride or sulphate), with reduction in uptake of important plant minerals (e.g. calcium, phosphorus, potassium, nitrogen) (69). In another study (70) explained about the sodium competition with calcium for binding site on membrane. So, hypothesis reported that, under salinity, cell membrane injury could be protected through increased calcium level in plant.

\section{Magnesium (Mg+)}

Magnessium is divalent cation and abundantly present in plants. Its function in cytosol of plant cell is important and worked in different physiological processes of plant (71). Absorption rate of magnesium strongly reduced under different environmental stresses and uptake of other cations e.g. potassium, calcium, hydrogen, aluminium, manganese and ammonium (72). In the present research high salt level $(150 \mathrm{mM} \mathrm{NaCl})$ application on wheat varieties caused significant reduction in plant height in both shoot and root regions as compare to their control. Reduction percentages at high salinity level were recorded in shoot as $18.4 \%$, 53.5\%, 35.8\%, $39.2 \%, 35.3 \%$ and $43.9 \%$ while in root region values were observed as 18\%, 23.7\%, 21.6\%, 30.5\%, 54.6\% and $23.5 \%$ in F. Sarhad, Insaf, Lalma, Tatora, Bathoor and Barsat respectively. F. Sarhad and Lalma varieties exhibited best performance for studied parameter as compare to other varieties (73) xplained that, during salinity stress, reduced uptake of calcium and magnesium through roots as well as these ions concentration reduced in leaves, as a result stability of membrane and chlorophyll content reduced in leaves.

\section{Carbon (C) and Oxygen (O-)}

In plants, balanced concentration of nutrients is necessary and important regulatory-factor for the maintenance of their nutritional quality as well as provides strength to tolerate the impacts of different environmental changes (74). Different studies revealed this fact that different environmental stresses cause disturbed ions uptake and nutrient imbalance in different crops. Current investigation revealed that high salt level $(150 \mathrm{mM} \mathrm{NaCl})$ application on wheat varieties caused significant promotion in carbon ion concentration in shoot and root regions as compare to their control with few exceptions. Promotion percentages at high salinity level were recorded in shoot as 3.6\%, 0.45\%, 3.6\%, $3.7 \%$ in F. Sarhad, Insaf, Lalma and Tatora respectively, while Bathoor and Barsat varieties exhibited $5.4 \%$ and $0.4 \%$ reduction in this ion level.
On the other hand, in root region values were observed as $2.9 \%, 0.6 \%, 7.8 \%, 0.59 \%$, and $16.4 \%$ in F. Sarhad, Insaf, Lalma, Tatora and Barsat respectively, while variety Bathoor exhibited $16.2 \%$ reduction in carbon ion concentration. Barsat and F. Sarhad varieties exhibited best performance for studied parameter as compare to other varieties. Under high salt stress condition plant undergo ionic stress which reduce plant growth as a result of accumulation of sodium and chloride ions with reduction of other important nutrients (e.g. calcium, carbon, nitrogen, potassium etc.) (75).

Presently, same research exhibited that high salt level (150 mM NaCl) application on wheat varieties caused significant promotion in carbon ion concentration in shoot and root regions as compare to their control with few exceptions. Promotion percentages at high salinity level were recorded in shoot as $3.6 \%, 0.45 \%, 3.6 \%, 3.7 \%$ in F. Sarhad, Insaf, Lalma and Tatora respectively, while Bathoor and Barsat varieties exhibited $5.4 \%$ and $0.4 \%$ reduction in this ion level. On the other hand, in root region values were observed as $2.9 \%, 0.6 \%, 7.8 \%, 0.59 \%$, and $16.4 \%$ in F. Sarhad, Insaf, Lalma, Tatora and Barsat respectively, while variety Bathoor exhibited 16.2\% reduction in carbon ion concentration. Barsat and $\mathrm{F}$. Sarhad varieties exhibited best performance for studied parameter as compare to other varieties. It has been observed in many experiments that exposure of different crops to salinity stress environment, stress cause osmotic and ionic stress as a result of high sodium and chloride ions level in plants. on the other hand, this increase of ions at toxic level cause reduction in absorption of other important macro (e.g. $\mathrm{K}, \mathrm{Mg}, \mathrm{Ca}, \mathrm{S}, \mathrm{P}$ ) and micro (Fe, $\mathrm{Cu}, \mathrm{Si}, \mathrm{Zn}$ etc.) nutrients and cause deficiency symptoms in plants (76-79).

\section{Nitrogen $(\mathrm{N})$}

Nitrogen is most abundant and important nutrient for plant growth and development. This element absorbed in plants in the form of nitrate and ammonium ion (80). Under stress conditions, specially under salt stress absorption and uptake of this element disturbed through immobilization of these ions, nitrate uptake compete with chloride ions while ammonium ions had competition with sodium ions $(81,82)$. In present study, high salt level (150 mM $\mathrm{NaCl}$ ) application on wheat varieties caused significant reduction in nitrogen ion concentration in shoot and root regions as compared to their control with few exceptions. Reduction percentages at high salinity level were recorded in shoot as $27.3 \%, 30.5 \%$, $4 \%, 30 \%$ and $40 \%$ in F. Sarhad, Insaf, Lalma, Tatora and Barsat respectively, while Bathoor variety exhibited 35.5\% promotion in this ion level.

On the other hand, in root region reduction values were observed as 33\%, 7.3\%, 4.7\%, and $19.3 \%$ in F. Sarhad, Insaf, Lalma and Bathoor respectively, while varieties Tatora and Barsat exhibited 3.4\% and $41.2 \%$ reduction in nitrogen ion concentration. Bathoor and F. Sarhad varieties exhibited best performance for studied parameter as compared to other varieties. When plants exposed to saline stress environment salt cause disruption of different 
membrane-proteins which cause changes in plasma membrane integrity which inturn negatively affect the absorption of ammonium and nitrate ions $(83,84)$ explained that competition caused as a result of low flux of nitrate ions from soil to plant root cause reduced activity of nitrate reductase activity which is a substrate inducible enzyme in plants.

\section{Phosphorus (P)}

Phosphorus is an important element in plant nutrition for proper growth and development. Availability of this element from soil to plant is hard as a result of its strong bonding while present in different in soluble forms. Mostly, plants develop different mechanisms as an adaptation to increase phosphorus absorption under its deficiency condition (85). According to the results of the present project, high salt level (150 mM NaCl) application on wheat varieties caused significant reduction in phosphorus ion concentration in shoot and root regions as compare to their control with few exceptions. Reduction percentages at high salinity level were recorded in shoot as $10.3 \%, 42 \%, 21.5 \%, 40.5 \%$ and $10.3 \%$ in F. Sarhad, Lalma, Tatora, Bathoor and Barsat respectively, while variety Insaf exhibited $2.9 \%$ promotion in this ion level. On the other hand, in root region reduction values were observed as $31.3 \%, 10.8 \%, 19.2 \%, 13.3 \%, 25 \%$ and $26.4 \%$ in $\mathrm{F}$. Sarhad, Insaf, Lalma, Tatora, Bathoor and Barsat respectively. Insaf and F. Sarhad varieties exhibited best performance for studied parameter as compare to other varieties. Observed that in different plant species, interaction between phosphorus absorption and saline stress condition is quite complex and not clear (86). It was reported that photosynthetic rate is dependent on phosphorus ion concentration in plants, so, reduction in phosphorus absorption results in reduced growth of plant (87).

\section{Sulfur (S)}

Plants absorb sulfur in the form of sulfate ion. Under saline condition, plants absorb and accumulate different ions (chloride, sodium, sulfates etc.) upto toxic level and cause osmotic stress, inefficiency of water use in plants as well as nutritional imbalance (65, 88-90). During the present study, high salt level (150 mM NaCl) application on wheat varieties caused significant reduction in sulfur ion concentration in shoot and root regions as compared to their control with few exceptions. Reduction percentages at high salinity level were recorded in shoot as 55..7\%, 33\%, $8.6 \%, 9.8 \%$ and $17.8 \%$ in F. Sarhad, Lalma, Tatora, Bathoor and Barsat respectively, while variety Insaf exhibited $26.9 \%$ promotion in this ion level. On the other hand, in root region reduction values were observed as $35.4 \%, 22.9 \%, 18.5 \%, 45.3 \%, 76 \%$ and $51.5 \%$ in F. Sarhad, Insaf, Lalma, Tatora, Bathoor and Barsat respectively. Insaf and Lalma varieties exhibited best performance for studied parameter as compared to other varieties.

\section{Silicon (Si)}

Silicon (Si) is an essential nutrient in plant growth, involve in alleviation of negative effects of salt stress through reduction in uptake of $\mathrm{Na}+$ and $\mathrm{Cl}$ - ions (59).
Currently, high salt level (150 mM NaCl) application on wheat varieties caused significant reduction in carbon ion concentration in shoot and root regions as compared to their control with few exceptions. Reduction percentages at high salinity level were recorded in shoot as 31\%, 16.3\%, 5.3\%, 9.8\% and 15\% in Insaf, Lalma, Tatora, Bathoor and Barsat respectively, while variety F. Sarhad exhibited $19.8 \%$ promotion in this ion level. On the other hand, in root region reduction values were observed as $30.9 \%$, $6.7 \%, 4.8 \%, 45 \%, 36.7 \%$ and $14.4 \%$ in F. Sarhad, Insaf, Lalma, Tatora, Bathoor and Barsat respectively. Barsat and F. Sarhad varieties exhibited best performance for studied parameter as compare to other varieties. Studies on aloe and tomato reported that increased level of calcium, magnesium and potassium after application of Si on plants (91). It was confirmed after their experiments, $\mathrm{Si}$ is involve in reduction in $\mathrm{Na}+$ ions uptake as well as take part in accumulation of $\mathrm{K}+$ ions with enhanced uptake of other essential minerals for normal growth and physiological functions of plant (92).

\section{Copper $(\mathrm{Cu}+)$}

Generally in plants, salt stress negatively affect absorption and translocation of micronutrients (e.g. zinc, copper, iron, manganese etc.) (86). Further, this stress also causes reduction in solubility and translocation of different micronutrients e.g. iron, copper, so, creating depletion environment around the root zone resulting reduced uptake of such nutrients (93). In current study, high salt level (150 $\mathrm{mM} \mathrm{NaCl}$ ) application on wheat varieties caused significant reduction in copper ion concentration in both shoot and root regions as compare to their control. Reduction percentages at high salinity level were recorded in shoot as $14.2 \%, 38 \%, 49.2 \%, 40.9 \%$, $19.7 \%$ and $44.9 \%$ while in root region values were observed as $43.3 \%, 36.2 \%, 32 \%, 40.1 \%, 38.9 \%$ and $34.4 \%$ in F. Sarhad, Insaf, Lalma, Tatora, Bathoor and Barsat respectively. Tatora and F. Sarhad varieties exhibited best performance for studied parameter as compare to other varieties. Solubility of different micronutrients (manganese, zinc, copper, iron) became low under salinity stress, so, when plants grow under such stress always develop sign of deficiency symptoms of these micronutrients (94). Studies are there correlating the availability of micronutrients under stress condition to the plant type/species and plant tissue (95). So, salt stress either cause promotion or reduction depend on plant species.

\section{Chloride (Cl-)}

Plant under salinity stress conditions, absorb sodium and chloride ions and accumulate them at extremely toxic levels (96). Plant roots functioned very well in salt tolerance mechanism and made different adaptive mechanisms to different adverse environments (97). During present investigation, high salt level (150 mM NaCl) application on wheat varieties caused significant promotion in chlorine ion concentration in both shoot and root regions as compare to their control. Promotion percentages at high salinity level were recorded in shoot as $256.9 \%$, $318 \%, 177 \%, 536 \%, 484.4 \%$ and $374.1 \%$ while in root 
region values were observed as $67.6 \%, 79.4 \%, 13.2 \%$, $137.4 \%, 388.6 \%$ and $182.2 \%$ in F. Sarhad, Insaf, Lalma, Tatora, Bathoor and Barsat respectively. Lalma and F. Sarhad varieties exhibited best performance for studied parameter as compare to other varieties. Different environmental stresses negatively affect the availability of ions in root zone as well as their uptake through roots $(93,98)$. Under saline stress condition affect plant growth through three different ways, i- reduction in water potential in root zone creating water deficiency, ii- imbalanced nutrients in plants through reduced uptake and transport of different ions, iii- accumulation of chloride and sodium ions causing phototoxicity of such ions (62).

\section{$\mathrm{K}+/ \mathrm{Na}^{+}$}

In plants, potassium sodium ratio $(\mathrm{K}+/ \mathrm{Na}+)$ is good indicator for their response to salt stress and usually increased in different plants after salt treatment (99). Salt stress creates two main effects in plants osmotic stress and ionic toxicity (100). Considerable promotion in sodium ion and significant decrease in potassium ions in plants create considerable promotion in sodium potassium ratio $\left(\mathrm{K}+/ \mathrm{Na}^{+}\right)(101)$. According to the present study, high salt level (150 $\mathrm{mM} \mathrm{NaCl}$ ) application on wheat varieties caused significant reduction in potassium sodium ratio in shoot and root regions as compare to their control with few exceptions. Reduction percentages at high salinity level were recorded in shoot as $20.6 \%$, 34.8\%, 26.9\%, 6.4\% in Insaf, Lalma, Tatora and Bathoor respectively, while F. Sarhad and Barsat varieties exhibited $38.6 \%$ and $507.5 \%$ promotion in this ratio. On the other hand, in root region promotion values were observed as 9\%, 14\%, 34.1\% and $21.9 \%$ in $\mathrm{F}$. Sarhad, Insaf, Bathoor and Barsat respectively, while varieties Lalma and Tatora exhibited $21.4 \%$ and $24.4 \%$ reduction in studied ratio. Insaf and F. Sarhad varieties exhibited best performance for studied parameter as compare to other varieties. With reduction of sodium ions uptake, potassium ion uptake enhanced in plants, with increase in $\mathrm{K}+/ \mathrm{Na}+$ ratio was also observed and this phenomenon also reported in Cicer aeritinum $(102,103)$.

\section{$\mathrm{Ca}+/ \mathrm{Na}+$}

During salt stress condition, in plants another important parameter to measure salt tolerance is calcium sodium ratio $\left(\mathrm{Ca}++/ \mathrm{Na}^{+}\right)(93)$. During present research, High salt level (150 $\mathrm{mM} \mathrm{NaCl}$ ) application on wheat varieties caused significant promotion in calcium sodium ratio in both shoot and root regions as compare to their control. Promotion percentages at high salinity level were recorded in shoot as $80.2 \%$, $21.4 \%, 9.8 \%, 18.04 \%, 28.3 \%$ and $1087 \%$ while in root region values were observed as $36.5 \%$, 59.5\%, $8.2 \%$, $10.6 \%, 151.5 \%$ and $88.8 \%$ in F. Sarhad, Insaf, Lalma, Tatora, Bathoor and Barsat respectively. Lalma and Tatora varieties exhibited best performance for studied parameter as compare to other varieties. Insaf showed more salt tolerance than the other cultivars. In saline environment due to high sodium ions in soil create less availability of calcium ions and hence limit plant growth (104). In saline stress condition, high sodium ions concentration in rhizosphere reduced the absorption of calcium ions through its replacement in plasma membrane and cell wall. This process results in low concentration of calcium translocation and causes reduction in calcium sodium ratio $\left(\mathrm{Ca}^{++} / \mathrm{Na}^{+}\right)(93)$. Low calcium sodium ratio cause reduction in cell turgor and hydraulic conductivity as well as creating disturbance in calcium ion signaling (105).

\section{Conclusion}

Environmental stresses including salinity stress can destroy the plant biochemical and physiological process and decrease the photosynthesis which affect plant growth and productivity. In this research we applied the salinity stress to different varieties of wheat in which salinity stress negatively influenced growth of different wheat varieties with reference to their vegetative and reproductive growth, different physiological attributes and ionomics of plants. Moreover, the wheat verities ' $F$. Sarhad, Insaf and Lalma showed more tolerance to salinity stress than other verities in various physiological and biochemical process. This work suggested that varieties F. Sarhad, Insaf and Lalma proved to be more salt tolerant as compare to other varieties, so, these are recommended for growing on moderately salt affected areas of KPK, Pakistan.

\section{Acknowledgements}

The authors would like to thank to Abdul Wali Khan University for providing suitable environment for research work.

\section{Authors' contributions}

HN conducted the experiments and collected the data. MA and HG supported in the experimental works, writing the manuscript by TY and YK, SS and $\mathrm{BA}$ performed statistical analysis. $\mathrm{KR}$ and $\mathrm{TY}$ hypothesized the paper concept and designed the experiment. Revised the manuscript by MS and MN.

\section{Conflict of interests}

The authors declare no conflict of interest.

\section{Supplementary files}

Fig. 1. Effect of different salt concentrations on biomass of different varieties of wheat

Fig. 2. Effect of different salt concentrations on wheat yield

Fig. 3. Effect of salt concentration on wheat ions

\section{References}

1. Munns R, Tester M. Mechanisms of salinity tolerance. Annual Review Plant Biololgy. 2008;59:651-81. https://doi.org/10.1146/annurev.arplant.59.032607.092911 
2. Singh AK. The physiology of salt tolerance in four genotypes of chickpea during germination. 2018. http://hdl.handle.net/123456789/4061

3. Ben-Arye E, Goldin E, Wengrower D, Stamper A, Kohn R, Berry E. Wheat grass juice in the treatment of active distal ulcerative colitis: a randomized double-blind placebo-controlled trial. Scandinavian Journal of Gastroenterology. 2002;37(4):444-49. https://doi.org/10.1080/003655202317316088

4. Alitheen NB, Oon CL, Keong YS, Chuan TK, Li HK, Yong HW. Cytotoxic effects of commercial wheatgrass and fiber towards human acute promyelocytic leukemia cells (HL60). Pakistan Journal of Pharmaceutical Sciences. 2011; 24(3):243-50.

5. Das A, Raychaudhuri U, Chakraborty R. Effect of freeze drying and oven drying on antioxidant properties of fresh wheatgrass. International Journal of Food Sciences and Nutrition. https://doi.org/10.3109/09637486.2011.644769

6. Hadjivassiliou M, Grünewald R, Sharrack B, Sanders D, Lobo A, Williamson C, Woodroofe N, Wood N, Davies-Jones A. Gluten ataxia in perspective: epidemiology, genetic susceptibility and clinical characteristics. Brain. 2003;126(3):685-91. https://doi.org/10.1093/brain/awg050

7. Foolad MR. Genome mapping and molecular breeding of tomato. International Journal of Plant Genomics. 2007. ID 643581-52 http://dx.doi.org/10.1155/2007/64358

8. Mengel K, Kirkby EA, Kosegarten H, Appel T. Nitrogen. In: Principles of Plant Nutrition 2001 (pp. 397-434). Springer, Dordrecht. https://doi.org/10.1007/978-94-010-1009-2_7

9. Akbari M, Toorchi M, Shakiba MR. The effects of sodium chloride stress on proline content and morphological characteristics in wheat (Triticum aestivum L.). In: Biological Forum. 2016;8: 379-35.

10. Shahid MA, Pervez MA, Balal RM, Ahmad R, Ayyub CM, Abbas $\mathrm{T}$, Akhtar N. Salt stress effects on some morphological and physiological characteristics of okra (Abelmoschus esculentus L.). Soil \& Environment. 2011;30(1):66-73.

11. Collado MB, Aulicino MB, Arturi MJ, Molina MD. Selection of maize genotypes with tolerance to osmotic stress associated with salinity. Agricultural Sciences. 2016;7. https://doi.org/10.4236/as.2016.72008

12. Yaycili O, Alikamanoğlu S. Induction of salt-tolerant potato (Solanum tuberosum L.) mutants with gamma irradiation and characterization of genetic variations via RAPD-PCR analysis. Turkish Journal of Biology. 2012;36(4):405-12.

13. Turan S, Cornish K, Kumar S. Salinity tolerance in plants: breeding and genetic engineering. Australian Journal of Crop Science. 2012;6(9):1337.

14. Ashraf M, Foolad MR. Crop breeding for salt tolerance in the era of molecular markers and marker-assisted selection. Plant Breeding. 2013;132(1):10-20.https://doi.org/10.1111/pbr.12000

15. García-Mata C, Lamattina L. Nitric oxide induces stomatal closure and enhances the adaptive plant responses against drought stress. Plant Physiology. 2001;126(3):1196-204. DOI https://doi.org/10.1104/pp.126.3.1196

16. Lutts S, Almansouri M, Kinet JM. Salinity and water stress have contrasting effects on the relationship between growth and cell viability during and after stress exposure in durum wheat $\begin{array}{lll}\text { callus. } & \text { Plant } & \text { Science. } \\ \text { 2004;167(1):9-18 }\end{array}$ https://doi.org/10.1016/j.plantsci.2004.02.014

17. Clarke JM, Mccaig TN. Excised-leaf water retention capability as an indicator of drought resistance of Triticum genotypes. Canadian Journal of Plant Science. 1982;62 (3): 57178. https://doi.org/10.4141/cjps82-086

18. Foolad MR. Recent advances in genetics of salt tolerance in tomato. Plant Cell, Tissue and Organ Culture. 2004;76(2):10119. https://doi.org/10.1023/B:TICU.0000007308.47608.88

19. Maggio A, Miyazaki S, Veronese P, Fujita T, Ibeas JI, Damsz B, Narasimhan ML, Hasegawa PM, Joly RJ, Bressan RA. Does proline accumulation play an active role in stress-induced growth reduction?. The Plant Journal. 2002;31(6):699-712. https://doi.org/10.1046/j.1365-313X.2002.01389.x

20. Cuartero J, Bolarin MC, Asins MJ, Moreno V. Increasing salt tolerance in the tomato. Journal of Experimental Botany. 2006;57(5):1045-58. https://doi.org/10.1093/jxb/erj102

21. Sattar S, Hussnain T, Javaid A. Effect of $\mathrm{NaCl}$ salinity on cotton (Gossypium arboreum L.) grown on MS medium and in hydroponic cultures. The Journal of Animal \& Plant Sciences. 2010;20:87-89.
22. Singla R, Garg N. Influence of salinity on growth and yield attributes in chickpea cultivars. Turkish Journal of Agriculture and Forestry. 2005;29(4):231-35.

23. Zeng L, Shannon MC. Effects of salinity on grain yield and yield components of rice at different seeding densities. Agronomy Journal. https://doi.org/10.2134/agronj2000.923418x

24. Taffouo VD, Wamba OF, Youmbi E, Nono GV, Akoa A. Growth, yield, water status and ionic distribution response of three bambara groundnut (Vigna subterranea (L.) Verdc.) landraces grown under saline conditions. International Journal of Botany. 2010;6(1):53-58.

25. Jaleel CA, Gopi R, Sankar B, Manivannan P, Kishorekumar A, Sridharan R, Panneerselvam R. Studies on germination, seedling vigour, lipid peroxidation and proline metabolism in Catharanthus roseus seedlings under salt stress. South African $\begin{array}{lll}\text { Journal of 2007;73(2):190-95. } & \text { Botany. }\end{array}$ https://doi.org/10.1016/j.sajb.2006.11.001

26. Anbumalarmathi J, Mehta P. Effect of salt stress on germination of indica rice varieties. European Journal of Biological Science. 2013;6(1):1-6.

27. Hartung W. Plant response to stress: Abscisic acid fluxes. In: Encyclopedia of Plant and Crop Science (Print) 2004; (pp. 97375). Routledge.

28. Jan S, Parween T, Siddiqi TO, Mahmooduzzafar. Antioxidant modulation in response to gamma induced oxidative stress in developing seedlings of Psoralea corylifolia L. Journal of Environmental Radioactivity. 2012;113:142-49.

29. Ashraf M. Relationships between growth and gas exchange characteristics in some salt-tolerant amphidiploid Brassica species in relation to their diploid parents. Environmental and Experimental Botany. 2001;45(2):155-63. https://doi.org/10.1016/S0098-8472(00)00090-3

30. Okçu G, Kaya MD, Atak M. Effects of salt and drought stresses on germination and seedling growth of pea (Pisum sativum L.) Turkish Journal of Agriculture and Forestry. 2005;29(4):237-42.

31. Taârit MB, Msaada K, Hosni K, Marzouk B. Physiological changes, phenolic content and antioxidant activity of Salvia officinalis L. grown under saline conditions. Journal of the Science of Food and Agriculture. 2012;92(8):1614-19. https://doi.org/10.1002/jsfa.4746

32. Mazher AA, El-Quesni EF, Farahat MM. Responses of ornamental and woody trees to salinity. World Journal Agriculture Science. 2007;3(3):386-95

33. Hutchings MJ, John EA. The effects of environmental heterogeneity on root growth and root/shoot partitioning. $\begin{array}{lll}\text { Annals } & \text { of } & \text { Botany. }\end{array}$ https://doi.org/10.1093/aob/mch111

34. Akbarimoghaddam H, Galavi M, Ghanbari A, Panjehkeh N. Salinity effects on seed germination and seedling growth of bread wheat cultivars. Trakia Journal of Sciences. 2011;9(1):4350.

35. Hajer AS, Malibari AA, Al-Zahrani HS, Almaghrabi OA. Responses of three tomato cultivars to sea water salinity 1. Effect of salinity on the seedling growth. African Journal of Biotechnology. 2006;5(10):855-861.

36. Basal HP. Response of cotton (Gossypium hirsutum L.) genotypes to salt stress. Pakistan Journal of Botany 2010;42(1):505-11.

37. Jafari $\mathrm{MH}$, Kafi $\mathrm{M}$, Astaraie A. Interactive effects of $\mathrm{NaCl}$ induced salinity, calcium and potassium on physiomorphological traits of sorghum (Sorghum bicolor L.). Pakistan Journal of Botany. 2009;41(6):3053-63.

38. Dadkhah AR, Grrifiths H. The effect of salinity on growth, inorganic ions and dry matter partitioning in sugar beet cultivars. Journal Agriculture Science Technology. 2006;8:199 210.

39. Cha-Um S, Kirdmanee C. Effect of salt stress on proline accumulation, photosynthetic ability and growth characters in two maize cultivars. Pakistan Journal of Botany 2009;41(1):8798.

40. Ghassemi-Golezani K, Taifeh-Noori M, Oustan S, Moghaddam M. Response of soybean cultivars to salinity stress. Journal Food Agriculture Environment. 2009;7(2):401-44.

41. Balibrea ME, Dell'Amico J, Bolarín MC, Pérez-Alfocea F. Carbon partitioning and sucrose metabolism in tomato plants growing under salinity. Physiologia Plantarum. 2000;110(4):503-11. https://doi.org/10.1111/j.1399-3054.2000.1100412 
42. Aloy M, Royo A, Aragues R. Effect of different levels of salinity on yield and yield components of 6 varieties of barley. Proceedings second congress of the European Society for Agronomy, Warwick University, 23-28 August 1992, Scaife, A (eds.).- Wellesbourne (United Kingdom): European Society for Agronomy, 1992.- ISBN 0-9519758-0-3. p. 26-27.

43. Srivastava JP, Gupta SC, Lal P, Muralia RN, Kumar A. Effect of salt stress on physiological and biochemical parameters of wheat. Annual Arid Zone. 1988;No.27:197-204.

44. Keutgen AJ, Pawelzik E. Quality and nutritional value of strawberry fruit under long term salt stress. Food Chemistry. 2008;107(4):1413-20.

https://doi.org/10.1016/j.foodchem.2007.09.071

45. Khan PS, Basha PO. Salt stress and leguminous crops: present status and prospects. Legumes under Environmental Stress: Yield, Improvement and Adaptations. 2015 Jan 12:21-51. https://doi.org/10.1002/9781118917091.ch2

46. Khatun S, Flowers TJ. Effects of salinity on seed set in rice. Plant, Cell and Environment. 1995;18(1):61-67. https://doi.org/10.1111/j.1365-3040.1995.tb00544.x

47. Krasensky J, Jonak C. Drought, salt, and temperature stressinduced metabolic rearrangements and regulatory networks. Journal of Experimental Botany. 2012;63(4):1593-608. https://doi.org/10.1093/jxb/err460

48. Abass SM, Latif HH. Germination and protein patterns of some genotypes of two species of jute as affected by $\mathrm{NaCl}$ stress. Pakistan Journal of Biological Sciences. 2005;8(2):227-34.

49. Sairam RK, Rao KV, Srivastava GC. Differential response of wheat genotypes to long term salinity stress in relation to oxidative stress, antioxidant activity and osmolyte concentration. Plant Science. 2002;163(5):1037-46. https://doi.org/10.1016/S0168-9452(02)00278-9

50. Abbasi GH, Akhtar J, Anwar-ul-Haq M, Ali S, Chen Z, Malik W. Exogenous potassium differentially mitigates salt stress in tolerant and sensitive maize hybrids. Pakistan Journal of Botany. 2014;46(1):135-46.

51. Pandey SN, Gautam S. Effect of nickel stress on growth and physiological responses of Trigonella foenum-graecum L. plants grown in Gomati upland alluvial soil of Lucknow. Indian Botanical Society. 2009;88(1):1-3.

52. Murillo-Amador B, López-Aguilar R, Kaya C, LarrinagaMayoral J, Flores-Hernández A. Comparative effects of NaCl and polyethylene glycol on germination, emergence and seedling growth of cowpea. Journal of Agronomy and Crop Science. 2002;188(4):235-47. https://doi.org/10.1046/j.1439037X.2002.00563.X

53. Arvin MJ, Donnelly DJ. Screening potato cultivars and wild species to abiotic stresses using an electrolyte leakage bioassay. Journal of Agricultural Science and Technology. 2008;10:33-42.

54. Kaya C, Tuna AL, Ashraf M, Altunlu H. Improved salt tolerance of melon (Cucumis melo L.) by the addition of proline and potassium nitrate. Environmental and Experimental Botany. 2007;60(3):397-403.

https://doi.org/10.1016/j.envexpbot.2006.12.008

55. Ghoulam C, Foursy A, Fares K. Effects of salt stress on growth, inorganic ions and proline accumulation in relation to osmotic adjustment in five sugar beet cultivars. Environmental and Experimental Botany. 2002;47(1):39-50. https://doi.org/10.1016/S0098-8472(01)00109-5

56. Youssef T, Awad MA. Mechanisms of enhancing photosynthetic gas exchange in date palm seedlings (Phoenix dactylifera L.) under salinity stress by a 5-aminolevulinic acid-based fertilizer. Journal of Plant Growth Regulation. 2008;27(1):1. https://doi.org/10.1007/s00344-007-9025-4

57. Demidchik V, Straltsova D, Medvedev SS, Pozhvanov GA, Sokolik A, Yurin V. Stress-induced electrolyte leakage: the role of $\mathrm{K}+$-permeable channels and involvement in programmed cell death and metabolic adjustment. Journal of Experimental Botany. 2014;65(5):1259-70. https://doi.org/10.1093/jxb/eru004

58. Bilgin O, Baser I, Korkut KZ, Balkan A, Saglam N. The impacts on seedling root growth of water and salinity stress in maize (Zea mays indentata Sturt.). Bulgarian Journal of Agricultural Science. 2008;14(3):313-20.

59. Ashraf M, Afzal M, Ahmed R, Mujeeb F, Sarwar A, Ali L. Alleviation of detrimental effects of $\mathrm{NaCl}$ by silicon nutrition in salt-sensitive and salt-tolerant genotypes of sugarcane (Saccharum officinarum L.). Plant and Soil. 2010;326(1-2):38191. https://doi.org/10.1007/s11104-009-0019-9
60. Liu F, Stutzel H. Leaf expansion, stomatal conductance, and transpiration of vegetable amaranth (Amaranthus sp.) in response to soil drying. Journal of the American Society for $\begin{array}{ll}\text { Horticultural } & \text { Science. }\end{array}$ https://doi.org/10.21273/JASHS.127.5.878

61. Erdei L, Taleisnik E. Changes in water relation parameters under osmotic and salt stresses in maize and sorghum. Physiologia Plantarum. 1993;89(2):381-87. https://doi.org/10.1111/j.1399-3054.1993.tb00170.x

62. Munns R. Comparative physiology of salt and water stress. Plant, Cell and Environment. 2002;25(2):239-50. https://doi.org/10.1046/j.0016-8025.2001.00808.x

63. Wang W, Vinocur B, Altman A. Plant responses to drought, salinity and extreme temperatures: towards genetic engineering for stress tolerance. Planta. 2003 ;218(1):1-4 https://doi.org/10.1007/s00425-003-1105-5

64. Munns R. Genes and salt tolerance: bringing them together. New phytologist. 2005;167(3):645-63. https://doi.org/10.1111/j.1469-8137.2005.01487.x

65. Hasegawa PM, Bressan RA, Zhu JK, Bohnert HJ. Plant cellular and molecular responses to high salinity. Annual Review of Plant Biology. 2000;51(1):463-99. https://doi.org/10.1146/annurev.arplant.51.1.463

66. Marschner H. Mineral Nutrition of Higher Plants. Academic Press, London, UK. 1995

67. Knight H, Trewavas AJ, Knight MR. Calcium signalling in Arabidopsis thaliana responding to drought and salinity. The Plant Journal. 1997;12(5):1067-78. https://doi.org/10.1046/j.1365-313X.1997.12051067.x

68. Bartels D, Sunkar R. Drought and salt tolerance in plants. Critical reviews in Plant Sciences. 2005;24(1):23-58. https://doi.org/10.1080/07352680590910410

69. Zhu JK. Plant salt tolerance. Trends in Plant Science. 2001 Feb 1;6(2):66-71.

70. Bush DS. Calcium regulation in plant cells and its role in signaling. Annual Review of Plant Biology. 1995;46(1):95-122. https://doi.org/10.1146/annurev.pp.46.060195.000523gr

71. Li L, Tutone AF, Drummond RS, Gardner RC, Luan S. A novel family of magnesium transport genes in Arabidopsis. The Plant Cell. 2001;13(12):2761-75. https://doi.org/10.1105/tpc.010352

72. Rengel Z, Robinson DL. Competitive Al3+ inhibition of net $\mathrm{Mg} 2+$ uptake by intact Lolium multiflorum roots: I. Kinetics. Plant Physiology. 1989;91(4):1407-13. https://doi.org/10.1104/pp.91.4.1407

73. Parida $\mathrm{AK}$, Das $\mathrm{AB}$, Mohanty $\mathrm{P}$. Investigations on the antioxidative defence responses to $\mathrm{NaCl}$ stress in a mangrove, Bruguiera parviflora: differential regulations of isoforms of some antioxidative enzymes. Plant Growth Regulation. 2004;42(3):213-26. https://doi.org/10.1023/b:grow.0000026508.63288.39

74. Nakandalage N, Seneweera S. Micronutrients use efficiency of crop plants under changing climate. In: Plant Micronutrient use Efficiency 2018 (pp. 209-224). Academic Press. https://doi.org/10.1016/B978-0-12-812104-7.00015-0

75. Ahmad S, Khan N, Iqbal MZ, Hussain A, Hassan M. Salt tolerance of cotton (Gossypium hirsutum L.). Asian Journal of Plant Sciences. 2002;1:715-19.

76. Kuşvuran Ş, Yaşar F, Abak K, Ellialtıoğlu Ş. Tuz Stresi Altında Yetiştirilen Tuza Tolerant ve Duyarlı Cucumis sp.'nin Bazı Genotiplerinde Lipid Peroksidasyonu, Klorofil ve İyon Miktarlarında Meydana Gelen Değişimler. Yüzüncü Yıl Üniversitesi Tarım Bilimleri Dergisi.2008;18(1):13-20.

77. Yilmaz e, tuna al, bürün b. The tolerance strategies that plants develop against salt strategy-tolerance strategies developed by plants to the effects of salt stress. Celal Bayar University Journal of Science. 2011;7(1):47-66.

78. Navarro A, Bañón S, Conejero W, Sánchez-Blanco MJ. Ornamental characters, ion accumulation and water status in Arbutus unedo seedlings irrigated with saline water and subsequent relief and transplanting. Environmental and $\begin{array}{lll}\text { Experimental } & \text { Botany. }\end{array}$ https://doi.org/10.1016/j.envexpbot.2007.10.010

79. Tuna AL, Kaya C, Ashraf M, Altunlu H, Yokas I, Yagmur B. The effects of calcium sulphate on growth, membrane stability and nutrient uptake of tomato plants grown under salt stress. Environmental and Experimental Botany. 2007 Mar 1;59(2):173-88. https://doi.org/10.1016/j.envexpbot.2005.12.007 
80. Frechilla S, Lasa B, Ibarretxe L, Lamsfus C, Aparicio-Tejo P. Pea responses to saline stress is affected by the source of nitrogen nutrition (ammonium or nitrate). Plant Growth Regulation. 2001;35(2):171-79. https://doi.org/10.1023/A:1014487908495

81. Hodge A, Fitter AH. Substantial nitrogen acquisition by arbuscular mycorrhizal fungi from organic material has implications for $\mathrm{N}$ cycling. Proceedings of the National Academy of $\quad$ Sciences. 2010;107(31):13754-59. https://doi.org/10.1073/pnas.1005874107

82. Miransari M. Arbuscular mycorrhizal fungi and nitrogen uptake. Archives of microbiology. 2011;193(2):77-81. https://doi.org/10.1007/s00203-010-0657-6

83. Köhler B, Raschke K. The delivery of salts to the xylem. Three types of anion conductance in the plasmalemma of the xylem parenchyma of roots of barley. Plant Physiology. 2000;122(1):243-54. https://doi.org/10.1104/pp.122.1.243

84. Hoff T, Stummann BM, Henningsen KW. Structure, function and regulation of nitrate reductase in higher plants. Physiologia Plantarum. 1992;84(4):616-24. https://doi.org/10.1111/j.1399-3054.1992.tb04712.x

85. Wissuwa $M$, Gamat G, Ismail AM. Is root growth under phosphorus deficiency affected by source or sink limitations?. Journal of Experimental Botany. 2005;56(417):1943-50. https://doi.org/10.1093/jxb/eri189

86. Grattan SR, Grieve CM. Mineral element acquisition and growth response of plants grown in saline environments. Agriculture, Ecosystems and Environment. 1992;38(4):275-300. https://doi.org/10.1016/0167-8809(92)90151-Z

87. Overlach S, Diekmann W, Raschke K. Phosphate translocator of isolated guard-cell chloroplasts from Pisum sativum L. transports glucose-6-phosphate. Plant Physiology. 1993;101(4):1201-17. https://doi.org/10.1104/pp.101.4.1201

88. Kim YH, Khan AL, Waqas M, Shim JK, Kim DH, Lee KY, Lee IJ. Silicon application to rice root zone influenced the phytohormonal and antioxidant responses under salinity stress. Journal of Plant Growth Regulation. 2014;33(2):137-49. https://doi.org/10.1007/s00344-013-9356-2

89. Shu K, Qi Y, Chen F, Meng Y, Luo X, Shuai H, Zhou W, Ding J, Du J, Liu J, Yang F. Salt stress represses soybean seed germination by negatively regulating GA biosynthesis while positively mediating ABA biosynthesis. Frontiers in Plant Science. 2017;8:1372. https://doi.org/10.3389/fpls.2017.01372

90. Rehman S, Abbas G, Shahid M, Saqib M, Farooq AB, Hussain M, Murtaza B, Amjad M, Naeem MA, Farooq A. Effect of salinity on cadmium tolerance, ionic homeostasis and oxidative stress responses in Conocarpus exposed to cadmium stress: Implications for phytoremediation. Ecotoxicology and $\begin{array}{lll}\text { Environmental } & \text { Safety. } & \text { 2019;171:146-53. }\end{array}$ https://doi.org/10.1016/j.ecoenv.2018.12.077

91. Li H, Zhu Y, Hu Y, Han W, Gong H. Beneficial effects of silicon in alleviating salinity stress of tomato seedlings grown under sand culture. Acta Physiologiae Plantarum. 2015;37(4):71. https://doi.org/10.1007/s11738-015-1818-7

92. Khan WU, Aziz T, Maqsood MA, Farooq M, Abdullah Y, Ramzani PM, Bilal HM. Silicon nutrition mitigates salinity stress in maize by modulating ion accumulation, photosynthesis and antioxidants. Photosynthetica. 2018;56(4):1047-57. https://doi.org/10.1007/s11099-018-0812-x
93. Grattan SR, Grieve CM. Mineral nutrient acquisition and response by plants grown in saline environments. Handbook of Plant and Crop Stress. 1999;2:203-29.

94. Page AL. Deficiencies and toxicities of trace elements. Agricultural Salinity Assessment and Management. ASCE Manuals and Reports on Engineering Practice. 1996;71:138-60.

95. Talei D, Kadir MA, Yusop MK, Valdiani A, Abdullah MP. Salinity effects on macro and micronutrients uptake in medicinal plant King of Bitters (Andrographis paniculata Nees.). Plant Omics J. 2012;5(3):271-78.

96. Teakle NL, Tyerman SD. Mechanisms of Cl-transport contributing to salt tolerance. Plant, Cell and Environment. 2010;33(4):566-89. https://doi.org/10.1111/j.1365-3040.2009.02060.x

97. Yang DS, Zhang J, Li MX, Shi LX. Metabolomics analysis reveals the salt-tolerant mechanism in Glycine soja. Journal of Plant Growth Regulation. 2017;36(2):460-71. https://doi.org/10.1007/s00344-016-9654-6

98. Orcutt DM, Nilsen ET. Physiology of plants under stress: Soil and biotic factors. John Wiley \& Sons; 2000.

99. Shabala S, Cuin TA. Potassium transport and plant salt tolerance. Physiologia Plantarum. 2008;133(4):651-69. https://doi.org/10.1111/j.1399-3054.2007.01008.x

100. Yadav S, Irfan M, Ahmad A, Hayat S. Causes of salinity and plant manifestations to salt stress: a review. Journal of Environmental Biology. 2011;32(5):667-85.

101. Fayez KA, Bazaid SA. Improving drought and salinity tolerance in barley by application of salicylic acid and potassium nitrate. Journal of the Saudi Society of Agricultural Sciences. 2014;13(1):45-55. https://doi.org/10.1016/j.jssas.2013.01.001

102. Xu CX, Ma YP, Liu YL. Effects of silicon (Si) on growth, quality and ionic homeostasis of aloe under salt stress. South African Journal of Botany. 2015;98:26-36. https://doi.org/10.1016/j.sajb.2015.01.008

103. Garg N, Bhandari P. Interactive effects of silicon and arbuscular mycorrhiza in modulating ascorbate-glutathione cycle and antioxidant scavenging capacity in differentially salttolerant Cicer arietinum L. genotypes subjected to long-term $\begin{array}{lll}\text { salinity. } & \text { Protoplasma. 2016;253(5):132545 }\end{array}$ https://doi.org/10.1007/s00709-015-0892-4

104. García-Sánchez F, Jifon JL, Carvajal M, Syvertsen JP. Gas exchange, chlorophyll and nutrient contents in relation to $\mathrm{Na}+$ and $\mathrm{Cl}^{-}$accumulation in 'Sunburst'mandarin grafted on different rootstocks. Plant Science. 2002;162(5):705-12. https://doi.org/10.1016/S0168-9452(02)00010-9

105. Läuchli A, Lüttge U. Salinity: Environment-Plants-Molecules. 2002:229-48, The Netherlands: Kluwer Academic Publishers.

106. FAO. 2015. Technical issues of salt-affected soils FAO. Technical issues of salt-affected soils.

107. Karimi M, De Meyer B, Hilson P. Modular cloning in plant cells. Trends in Plant Science. 2005;10(3):103-35.

108. Jan S, Parween T, Siddiqi TO. Enhancement in furanocoumarin content and phenylalanine ammonia lyase activity in developing seedlings of Psoralea corylifolia $\mathrm{L}$. in response to gamma irradiation of seeds. Radiation and Environmental Biophysics. 2012 ;51(3):341-47. 